\author{
Antonius Tri Wibowo', Asna Syafitri², Dody Tri Iwandana ${ }^{3}$ \\ Mercu Buana University Yogyakarta
}

\title{
Psychological characteristics of PSIM Yogykarta players in wading the League 2 soccer competition in 2019/2020
}

\begin{abstract}
This study aims to determine the psychological characteristics of PSIM Yogyakarta players in wading the League 2 competition. Data collected from 27 players who are members of the PSIM Team in 2019 can be concluded that PSIM players totaling 27 people have characteristics for the aspect of motivation with a mean (38.6) with a percentage (97\%), included in the category (very high). As for the aspect of confidence, PSIM players have an average (30) with a percentage $(83 \%)$ in the (very high) category. For anxiety control aspect, it has average (27.6) with percentage (79\%) and categorized (High), mental preparation aspect has average (18) with percentage $(60 \%)$ and categorized (Medium), aspect of team attention has average (14) with a percentage $(71 \%)$ and included in the category (High), and the Concentration aspect had an average (23.8) with a percentage (76\%) and included in the category (very High).
\end{abstract}

Keywords: characteristic, PSIM player

\section{Introduction}

The success of PSSI in the holding of the National football named Liga 1, Liga 2 and Liga 3 (Liga Nusantara) generates new hope for Indonesian football, although it cannot be separated from some unfavorable records of referee leadership, supporters riots and fights between players, but PSSI continues to look forward with various programs that continue to be rolled out for the advancement of football in the country of Indonesia. In June 2019 PSSI planned to start a professional football competition in Indonesia with the name League 1 for the highest level of competition, League 2 for the second caste and the lowest was League 3, a preparation for professional competition. Quality sports and competition achievements will be a support for a country to get respect from other countries, therefore the government formulated law number 3 of 2005 concerning the national sports system and was strengthened again by the government and the Parliament established law number 16 in 2007 related to

\footnotetext{
${ }^{1}$ Antonius Tri Wibowo, e-mail: antoniustriwibowo@mercubuana-yogya.ac.id

${ }^{2}$ Asna Syafitri, e-mail: asna@mercubuana-yogya.ac.id

${ }^{3}$ Dody Tri Iwandana, e-mail: dodytriiwandana@mercubuana-yogya.ac.id, ORCID: 0000-0003-3545-9877
} 
the implementation of sports so it is expected that with embassies and support from the government the achievements of Indonesian sports will increase.

In article 20 and article 74 of law number 3 of 2005 concerning the sports system, it is stated that achievement sports are carried out through a planned, tiered, and sustainable development and development process with the support of sports science and technology. All of these arrangements will always be supported by the central and regional governments and the community can develop science and technology on an ongoing basis to advance national sports, through research, studies, technology transfer, socialization, scientific meetings and cooperation between research institutions both domestically and abroad (President and Parliament, 2005).

Strengthening more specifically contained in article 1 and article 72 of Law number 16 of 2007, article 1 regarding the development of sports science and technology is to improve the quality and quantity of knowledge and technology aimed at utilizing scientific methods and theories which have been proven to be correct for the improvement of functions, benefits, and application of existing science and technology or produce new technology for sports activities. Article 72 contains the government, regional government and the community responsible for carrying out the development of sports science and technology in a planned and sustainable way to advance national sports. Therefore, there is an awareness that to excel in sports does not only depend on one factor but many factors, namely science and technology being supporting factors besides the quality of athletes, coaches and facilities so that collaboration will create superior quality athletes so that they can become champions. support for using the knowledge stated in Article 74 the development of sports science and technology is directed to develop basic science and applied science in the field of sports.

The urgency of international standard sports development by including sport science is very necessary to be able to catch up with the achievements of other countries, therefore all parties, both the central government, regional governments, sports institutions and educational institutions that focus on sports must synergize to be able to work together together realize the dream of becoming the best in the world of sports. The growing science of sports requires the coaches and coaches of sports to always learn, otherwise they will definitely be left behind by the increasingly varied training methods. Bompa (1999) said that in theory and training methods are composed by several supporting sciences, including physiology, psychology, biomechanics, nutrition, psychology, tests and measurements, sociology and motor motion, so it is expected that each trainer is able to understand science that and will always try to improve the achievements of the athletes as high as possible.

Efforts to improve performance in sports require supporting science, namely anatomy, sociology, physiology, sports medicine, biomechanics, statistics, tests and measurements, psychology, motor learning, education, nutrition and history so that all become one part in improving the quality and ability athletes (Bompa in Emran, 2017). Pate, McCleanaghan, and Rotella (in Dimyati \& Hastuti, 2013) stated more specifically that until now there are three basic sciences that have developed into sub- 
disciplines that support the practice of perfect sportsmanship training, namely Biomechanics, Exercise Psychology, and Sports Psychology. The opinion of the experts above shows that sport needs to get support from other scholarships that can be a good collaboration to create a champion athlete.

According to William \& Reilly in (Dimyati \& Hastuti, 2013) stated that based on several studies conducted on the branches of soccer there are some psychological characteristics that need to be possessed by young athletes, namely the level of arousal control, self-confidence and the capacity to appear energetically. Sports psychology in particular is concerned with the emotional mentality of athletes becoming increasingly decisive contributors in the coaching and enhancement of athlete achievement (Singgih, Monthy, \& Myrna, in Dimyati \& Hastuti, 2013). There are some experts from sports experts that $80 \%$ of sports are influenced by mental and psychological sports while $20 \%$ are other factors so you can imagine how important psychological factors are in sports, don't let athletes experience unequal performance between when training is so good while at the time of the match did not even show the best. The professional branches of golf as well as the poorness of their appearance in a match are largely determined by psychological factors, namely anxiety, somatic, cognitive anxiety, attention control, and emotional control (Julien Bois, Philippe Sarrazin, Julien Southon, 2009).

High achievement is not only supported by physical factors, techniques, and tactics, but psychological factors also determine. Athletes must have calm when competing in order to minimize mistakes in passing and shooting so that the resulting ball can be right on target so that there is a reciprocal relationship between psychic and physical, meaning that if psychological factors are disrupted it will result in physical work and motor movements are also disrupted, and vice versa (Hildan Efendi \& made Pramono, 2016). Cox, Liu and Qiu in (Dimyati \& Hastuti, 2013) conducting research on professional athletes in China found that elite athletes have high self-confidence and emotional control, of course as professional players are expected to have complete physical, technical and mental abilities. Martial arts (pencak silat, taekwondo, and karate) are needed psychological factors such as concentration, anticipation, emotional control, self-control, self-confidence and fighting spirit, if you do not have some of these factors, you will likely experience failure in the match (Joaquin Dosil, 2006) . Dimyati \& Hastuti (2013) stated that in general team athletes have more anxious, dependent, open and alert characteristics, but are less sensitive and imaginative than individual athletes.

Psychological problems in several matches caused defeat as stated by Ivan Kolev, a coach of the PS TNI Professional Soccer Team, his team suffered goals conceding during injury time against the Newcastle team due to the lost athlete's concentration which caused PS TNI to experience defeat at the Komptisi Liga1 2017 (Permana Kusumadijaya, 2017). Some of the literature above shows how important psychological factors are for athletes' achievement, we can imagine "an athlete with almost perfect physical and technical abilities but at the time of the competition has a problem because the psychological factors of athletes experience loss of selfconfidence, excessive anxiety, lost concentration, enthusiasm his struggle is lost and 
finally his emotional control also goes away what happens? we can be sure that the athlete will not display optimal performance". Different cases if an athlete has good physical and technical abilities and is supported also has a mental psychological quality, perhaps in an official match it will be able to display optimal performance. Psychological training becomes one of the most important things but sad things are sometimes still not enough attention for the trainer to be applied in the training process, the trainer still adopts and implements the old training system which only emphasizes the physical sector, technique and tactics. Psychological training concerning aspects psychological aspects such as maintaining focus on concentration, setting arousal levels, increasing trust, and maintaining motivation need to be done systematically (Weinberg \& Gould, 2015).

Until now, coaches still emphasize training on athletes only on physical, technical and tactic, whereas psychological factors are completely untouched (Suryanto, 2011). In the ranks of the policy the sports coaches have not seen the importance of sports psychology coaching in the coaching and mentoring of national athletes who will be sent to important sporting events at the international level (Dimyati \& Hastuti, 2013). The researcher's own experience as a former professional soccer athlete competing in national football and previous research conducted by researchers on professional basketball athletes competing at the 2017 Indonesian Basketball Ball Ligue which incidentally is the highest competition in basketball in Indonesia shows how the lack of psychological training of athletes and even athletes has not have experienced psychological tests (Tri Wibowo Antonius, 2016).

The national football season will start soon in 2018, participating teams that will compete in either League 1, League 2 or League 3 have prepared themselves to build their team strength by recruiting their players, after getting the team players to continue training camps. Whereas PSIM itself is a legendary football club that competes in Mandala Krida which incidentally is a proud club of Yogyakarta Special Region before the emergence of PSS Sleman and PERSIBA. PSIM now competes in League 2 and in the last 10 years its best achievement is to win 1st division 1 in 2006 and after that PSIM Yogyakarta always struggles at the peak of the 2017 competition PSIM must undergo a play-off match to continue to survive in this League 2 competition. Many factors cause PSIM Yogyakarta's performance to fade, including financial difficulties, internal conflicts within supporters, totality of management in preparing teams, political interests and not yet optimally using sport science in team management. Seeing the concerns of the Yogyakarta PSIM team's condition and the history ties between the researchers and the Yogyakarta PSIM club which incidentally the researchers themselves have strengthened the PSIM Yogyakarta team and from the results of previous interviews in the past few years the PSIM team has never conducted a psychological training program, in fact psychological testing has never been done to the player. Therefore after the researcher became an educator / lecturer in the field of sports, the researcher collaborated with the PSIM team management to conduct a psychological test. Based on the background above and the 
study of the theory above, the hypothesis in this study is how are the psychological characteristics of PSIM players in 2019?

\section{Methodology}

The research method used in this study is the longitudinal survey method (gathering data cumulatively over time). The subjects in this research are all 27 PSIM players and are professional players aged 20-38 years. This research in taking data using a questionnaire using instruments named PSIS-R-5 developed by Mahoney, Gabriel, and Perkins (M.J.Mahoney, J.Gabriel, \& Perkins, 1987). This instrument consists of 44 statement items designed to measure psychological characteristics related to sports background. This instrument consists of six aspects of psychology, namely motivation, self-confidence, anxiety control, mental preparation, team attention and concentration. Before being used as an instrument in this research, the following steps were taken: (1) Translated by English experts; (2) the translated instrument was subsequently assessed by three experts; (3) and subsequently tested on athletes who have characteristics similar to research subjects. As for the reliability and validity of the instruments following from the previous assessment.

Analysis of the data in this study were in several stages, the first stage was checking data collected from all 27 PSIM participants. The second step was scoring each subject's answer to the questionnaire. The third stage of the data obtained is then analyzed to describe the psychological characteristics of athletes including aspects of motivation, self-confidence, anxiety control, mental preparation, team attention and concentration.

\section{Results and discussion}

The results of the analysis of the data after the instrument questionnaire got a score produced the data that PSIM Yogyakarta players in 2019 are as follows:

Table 1. Psychological Characteristics Categories

\begin{tabular}{|c|c|c|c|c|}
\hline \multirow{2}{*}{ Number } & \multirow{2}{*}{$\begin{array}{c}\text { Psychological } \\
\text { aspects }\end{array}$} & \multicolumn{3}{|c|}{$\mathrm{N}=27$} \\
\cline { 3 - 5 } & Average & Percentage & Categories \\
\hline 1 & Motivation & 38,7 & $97 \%$ & Very high \\
\hline 2 & Confidence & 30 & $83 \%$ & Very high \\
\hline 3 & Anxiety Control & 27,6 & $79 \%$ & High \\
\hline 4 & Mental preparation & 18 & $60 \%$ & Medium \\
\hline 5 & Attention Team & 14 & $71 \%$ & High \\
\hline 6 & Concentration & 23,8 & $76 \%$ & Very high \\
\hline
\end{tabular}


From Table 1 it can be explained that there are 27 PSIM players who have characteristics for the aspect of motivation with an average (38.6) with a percentage (97\%), included in the category (very high). As for the aspect of confidence, PSIM players have an average (30) with a percentage (83\%) in the (very high) category. For anxiety control aspect, it has average (27.6) with percentage (79\%) and categorized (High), mental preparation aspect has average (18) with percentage $(60 \%)$ and categorized (Medium), aspect of team attention has average (14) with a percentage $(71 \%)$ and included in the category (High), and the Concentration aspect had an average (23.8) with a percentage (76\%) and included in the category (very High).

\section{Conclusion}

Based on the data it can be concluded that the PSIM Yogyakarta team in facing the League 2 competition held by PSSI has very high motivation, confidence, and concentration in the category, for anxiety control and PSIM player concentration is in the high category, while the mental preparation of PSIM players is in the medium category . From the results of this research, hopefully it can help the coach in assisting players in terms of psychological aspects by focusing on the mental preparation aspects because for the level of professional soccer players, ideally all psychological characteristics are included in the excellent category.

\section{References}

Bompa, T. O. (1999). Periodization Training for Sports. Human Kinetics. Retrieved from https://is.muni.cz/el/1451/podzim2015/np2319/um/Periodization_Training for_Sport.pdf

Dimyati, \& Hastuti, H. (2013). Karakteristik Psikologis Atlet di Pusat Pendidikan dan Latihan Pelajar ( PPLP ). Jurnal Psikologi UGM, 40(2), 143-158. Retrieved from $\quad$ https://text-id.123dok.com/document/y49m36rz-karakteristikpsikologis-atlet-di-pusat-pendidikan-dan-latihan-pelajar-pplp-dimyatijurnal-psikologi-6973-27101-1-pb.html

Emran. (2017). Pengantar Teori dan Metodelogi pelatihan Fisik (edisi Pert). Depok: Pt Kencana.

Hildan Efendi \& made Pramono. (2016). Kajian Kecemasan Atlet Hockey Putra Kabupaten Gresik Sebelum Bertanding di PORPROV Jawa Timur Tahun 2015. Jurnal Kesehatan Olahraga, 6, 5-10.

Joaquin Dosil. (2006). The Sport Psychologist's Handbook: A Guide for SportSpecific Performance Enhancement. The Sport Psychologist, 515-516. Retrieved from 
http://www.humankinetics.com/acucustom/sitename/Documents/Documen $\underline{\text { tItem/6290.pdf }}$

Julien Bois, Philippe Sarrazin, Julien Southon, J. B. (2009). Psychological Characteristics and Their Relation to Performance in Professional Golfers. The Sport Psychologist, 23(2), 252-270. https://doi.org/10.1123/tsp.23.2.252

M.J.Mahoney, J.Gabriel, T., \& Perkins, T. S. (1987). Psychological Skills and Exceptional Athletic Performance. The Sport Psychologist, 1(3), 181-199.

Permana Kusumadijaya. (2017). Konsentrasi dan Kondisi Lapangan Jadi Biang Kekalahan PS TNI - Indonesia Bola.com. Retrieved February 26, 2018, from $\quad$ http://www.bola.com/indonesia/read/3067316/konsentrasi-dankondisi-lapangan-jadi-biang-kekalahan-ps-tni

Presiden dan DPR. UU RI No.3 Tahun 2005 Tentang Sistem Keolahragaan (2005). Indonesia. Retrieved from http://www.dpr.go.id/dokjdih/document/uu/45.pdf

Suryanto. (2011). Identifikasi kondisi psikologis (mental) atlet junior cabang olahraga panahan di daerah istimewa yogyakarta. Medikora, 7, 1-73. Retrieved from https://journal.uny.ac.id/index.php/medikora/article/view/4659

Tri Wibowo Antonius. (2016). Gaya Hidup, Kebugaran Jasmani, dan Konsentrasi Atlet Bolabasket Tim Satya Wacana Salatiga Menghadapi INDONESIAN BASKETBALL LEAGUE (IBL) 2017. Sportif, 2(2), 76-84.

Weinberg, R. S. (Robert S., \& Gould, D. (2015). Foundations of sport and exercise psychology (6th ed.). Miami: HKRewards. 